\title{
Development of Standard Albanian after the Second World War
}

\author{
Dr. Manola Kaçi (Myrta)
}

“Aleksandër Moisiu” University, Durrës; manola.myrta@yahoo.com

\section{Doi:10.5901/mjss.2016.v7n3s1p268}

\section{Abstract}

\begin{abstract}
Standard Albanian and its development are widely treated and discussed issues. As already known, the efforts to create this linguistic variant have been relatively early, even though tougher debates have emerged mainly over the 1944-1956s. This period coincides with two important and popular sections of 1952, in which took place a lot of polemics about the standard Albanian. The study aims at presenting an overview of some of attitudes toward standard Albanian version during the period of 1944-1956s. Another aim of this study is to clearly reflect the fact that, even before 1944 was spoken and taken concrete decisions (even by the state itself in 1923), in creating the standard based on the literary dialect of Elbasan, in these sessions this idea was completely rejected. During the discussions is clearly visible the attitude held on literary Tosk and the reasons given to why this linguistic option should constitute the basis for the creation of future Albanian standard. These attitudes constituted the "path" in which the Spelling Congress would walk further.
\end{abstract}

Keywords: sessions, attitudes, arguments, literary Tosk, standard Albanian

\section{Introduction}

The standard variant of a language is in itself a "very heavy stone" in the foundations that ensure the continuity of the existence of a nation. In the perspective of the scholar Gjovalin Shkurtaj the Albanian standard version is considered as an "honorable lady whom we should grant all the love, care and professionalism." And, indeed, this is the foundation upon which should be based all the decisions, attitudes or changes in any aspect related to the language in each period of time.

But let's go back to the Albanian past. If we take a look at the history of creation of the standard Albanian language, we will easily distinguish that the process of its formation has gone through a series of streams, which have been closely linked to the historical and social conditions in which Albania has gone through as a nation.

At this point, we refer again to the linguist Gjovalin Shkurtaj who, correctly, stated that: "The need for a common and unified language, the same for the whole nation, is greater in periods of creating national and state unity, when creating relevant nations and states (Gjinari, Shkurtaj, 2000, p. 32).

And indeed, if the strands to create standard Albanian trace back earlier, sometime troubled and sometimes clearer, rapid events and heated debates about the formation of the standard Albanian language were developed in the time period 1944-1956.It is associated to the two highly debated popular sections of 1952. During this period, important steps were taken by using existing potentials to resolve the common linguistic variant. However, one thing is known, that until 1944 was in force the Albanian Government decision taken in 1923 to support the conclusions reached in 1916 by the Literary Commission of Shkodra, as well as the Educational Congress of Lushnja in 1920. Even in 1940 the first Assembly of Albanian studies reaffirmed the conclusions reached, saying that the foundations of the official language were the Elbasan dialect with the powerful influences of Shkodra pens and the Tosk writers (Komisia Letrare Shqipe në Shkodër, Shkodër, 1997, p. 70).

It was the inherited situation after World War II, until 1944-1945. Regarding this reality, says linguist B. Beci, still it is not known if immediately after the 1944-1945 war were made any scientific activities with a national character to have scientifically examined the problem or to have come up with a better decision or if it was made a "social contract" to remove literary Gheg as an official language and to replace it with the literary Tosk. Instead another decision was made: in 1945, when the Minister of Press, Propaganda and Popular Culture in Albania was Sejfulla Malëshova, "Gheg began to be removed from the press" (Ismajli, 2005, p. 138); when he switched to the Ministry of Education in 1946, Gheg began to be removed from school books (Ismaji, 2005, p. 138).

Meanwhile, on 28 January 1947, it was decided that the Institute of Studies would become autonomous. The Institute had issued its internal regulationin in literary Gheg. In his speech, during the inauguration of the Institute, M. Konomi (chairman of the Ministerial Council) said: "the literary language, the common national language should not be 
taught of the mass of the people who represent the most progressive part of our country. The road opened by the people with the war should be the way the language should follow in its development. Language development in a different direction or in a reverse direction is not possible. This is the criteria that should lead our work" (Ismajli, 2005, p. 117)

Still in 1947 a commission composed of linguists such as A.Xhuvani, K.Cipo and E. Cabej had developed the orthography rules which were published in the Bulletin of the Institute of Science II (04/01/1948), and, after the discussion made in 1951, "Albanian Language Spelling" was published in a special booklet. In the same year, the Ministry of Education made the decision, according to which, in the early grades of elementary school of the north lessons were to be taught in Tosk. This replacement with the Tosk dialect was a revolution in the true sense (Ismajli, 2005, p. 116).

However, in 1952 this problem appeared with a series of controversies. During this period, in Tirana, were taken a series of very important steps. In circles of the linguists, intellectuals and writers were dissatisfaction with the situation in this area even earlier when "the official language was Gheg and when it was thought that with the time it could be the general national literary language" (Ismajil, 2005, p. 116).

\section{Literature Review}

Not surprisingly, January 1952, is considered as the period in which discussion on the issue of standard Albanian significantly increased, at which point the Institute of Science in Tirana held the first Session as it follows: "The works of Comrade Stalin on linguistics and our linguistic problems in the light of these works".

Let's take a look at the perspective of the most prominent discussions held at this session.

In a lecture held by Mynir Reso, professor of the High Pedagogical Institute, M.Reso gave the conclusions regarding the standard Albanian. According to him, under the Turkish rule the Albanian language, as an official language, was forbidden, so the Albanian writing had stopped. Further, he says that: "But the living language of the people serves as a basis for the formation of the Albanian literary language on nationality grounds, which apparently started in the second half of the nineteenth century, when the Albanian literature began to develop in new historical conditions" (Ismajli, 2005, p. 118). Following his speech, Reso thought that the grounds for this were prepared by Konstandin Kristoforidhi, while a major contribution in the development of literature was brought by the national poet Naim Frasheri (Ismajli, 2005, p. 119).

Attention in this session was drowning by the discussion made by Dhimiter Shuteriqi (Vice President of the League of Albanian Writers and member of the Institute of Sciences). He rebuked the wrong way to treat the problem of our national language and, in his opinion; the issue could find the solution in our history from the Renaissance onwards: Tosk, in the development of our people at this stage of its history, became the main written dialect and the literary basis of our language.

According to him, the difference between our two dialects was not so great, but the Tosk dialect was made the main written dialect because:

- $\quad$ "South of Albania" was more developed compared to the North in the economic, social and cultural view, it was the cradle of the national movement of Renaissance

- Albanian colonies in emigration consisted mainly of Tosks

- ideologists, movement leaders and writers were from the south

- Most of those who wrote at that time were from the south

- $\quad$ literature with a greater prevalence in the south managed to penetrate even in central Albania.

According to Shuteriqi, Tosk continued to evolve and penetarted even to Ghegs through the press, which was mainly in Tosk. In front of a unique Tosk, were written two Ghegs: the one of Elbasan and that of Shkodra. He thought that in the years 1930-1935, Shkodra writers made concessions toward the language of Elbasan: "Austria through 'Literary Commission '(1917), King Zog through his Ministry of Education, Italy with Mustafa Kruja and Institute of Albanian studies, who more and who less, supported some Gheg language writers and scholars to announce the subdialect of Elbasan as the official language" (Myrta, 2014, p. 39). His idea is already known for a collaboration between dialects, the idea for which he blamed Sejfulla Malëshova who, in 1945, required that Tosk to be recognized as the official language and to develop without the interfering with the Gheg: "this way he wanted to raise a great wall between the two dialects, to isolate one from another of the to discourage the normal development of Tosk as the only literary language enriched by Gheg elements" (Ismajli, 2005, p. 121).

The Head of the Department of Language of the Literature, Alexander Xhuvani in his speech noted that this issue found resolution in the war and during this period of reconstruction, when the Tosk got a big burst, it won superiority and it is progressing towards the establishment of a common written language, putting an end to all those efforts that were made in past times to create a common written language (Ismajili, 2005, p. 122). 
The associate of the Institute of Sciences, Lirak Dodbiba held the following attitude: "The fact that the word of our Labour Party, during the war was said in Tosk and all the masses of the people and our employees, Tosk and Gheg, arose under its leadership in the fight to liberate the country to take the power in hand, the fact that today the entire nation is mobilized this word of the Party in action to build the foundations of socialism in our country, and the Ghegs themselves do not feel the difference of the dialect in this speech, these facts show that our people, with all its dialects, has a common national language represented by the Tosk dialect " (Ismajili, 2005, p. 124). To have such a Tosk, from one side it should be the official language (office and school), but on the other side even the Gheg dialect should be allowed to flourish in the field of literature ..." The coexistence of the Gheg element will therefore enrich and perfect the national language" (Ismajli, 2005, p. 124). Thus, he raised the problem or of the use of Gheg, at least, parallel and to unofficial functions, thus refusing the idea of its total elimination. At the conclusion of this session a conclusion was reached: "Most of the discussions believe that the language on which to rely for the formation of national literary language is the Tosk enriched with words, expressions and forms of the Gheg" (Ismajli, 2005, p. 125).

Based on the historical facts submitted above, the discussion of this session overthrew the decision of the Literary Commission of Shkodra, regarding the inclusion of the two Albanian dialects to create the standard version of Albanian. Now, although there was a slight cooperation between the two dialects, it was noticed quite significantly the dominance of the idea to establish literary Tosk as the linguistic version on which the standard Albanian would be based and one of the reasons that warrant this choice was exactly that: during the war "the word of the Party" was said in Tosk.

The problem of a national common language was decided in the heart of the second scientific session held at the Department of Language and Literature of the Institute of Science, held on 10, 11 and 12 September. Even in this Session dominated almost the same figures who also appeared in the first session.

At this meeting Dh. Shuteriqi in his lecture "On the Albanian a national literary language" held the same attitude as in the first section. Shuteriqi contested the unsupported opinion that in the years 1925-1944 "the northern dialect prevailed in education and administration, because the state had given specific orders that acts and textbooks be written in this dialect", adding that "such an order had been given, for example in 1922, officially" because, according to him,"the majority of the employees originating from the south continued to write the acts in their dialect... The after war time made Tosk an official language, language of the education, science, media and propaganda, and of the majority of fiction" (Ismajil, 2005, p. 127).

If we go back to the position of Shuteriqi we encounter this statement: "The national War brought a number of new employees, who seized the reins of the state and of all social activity. The new staff was especially from the south, because there was the great movement of the war. These employees using their dialect in written language made it, spontaneously superiorior than other dialect". (Ismajli, 2005, p. 128).

He held the same position on the idea of involving the Gheg linguistic elements in Tosk-based standard language, for which did not have the idea to remain "pure" and thought that "the interdialect cooperation is inevitable". After discussing some enrichment points of the national Tosk-based literary language with elements of Gheg in the phonetics aspect, Shuteriqi noticed a point of interdialect approach - that of the infinitive (Ismajili, 2005, p. 128).

Alexander Xhuvani holds a position opposite to that of Shuteriqi. First, he finds to be problematic Shuteriqi's attitude, according to whom Tosk was written during the Renaissance and later. According to Xhuvani, in that period, in texts both Gheg and Tosk were used almost the same way. "Since the formation of the Albanian State or better since the Congress of Lushnja until the recent times, in the press prevailed the use of Tosk, whereas in the administration, in education, such as textbooks, etc. etc. prevailed the use of Gheg ... However "both dialects" were balanced, but the time would come "to merge to a common language ... I once had this opinion, this merging of the two dialects, letting them free in their development" (Ismajili, 2005, p. 131).

Meanwhile, Malëshova Sejfulla held an open attitude for literary Tosk, the Tosk of Naim Frasheri, for the "lively" Tosk and was against the proposals of Shuteriqi to introduce the infinitive, " -ues" nouns form of Gheg, "-ueshëm" Gheg adjectives. According to him: "Tosk should be enriched with words and expressions from the Gheg. It may even take any forms from Gheg, but it must maintain its physiognomy, its characteristic features" (Ismajli, 2005, p. 133).

Ressuli was against the idea of the Elbasan dialect as the literary standard language. In his speech he focused especially on the factors which led to the proliferation of the Elbasan dialect. Namely, he said: "Nor did the Literary Commission of Shkodra, with all traces that they left in many writers, especially the Gheg ones, be approved and spread across Albania; thus, they were not made 'national'. This way, the common language problem is still unsettled and all the philologists struggled and are still struggling without resolving it." (Ismajli, 2005, p. 78)

In 1952, Idriz Ajeti holds the same attitude to that of Ressuli considering it impossible to have the dialect of Elbasan as the Albanian literary language, and for this, he is based on the fact that there is no valuable literature in this dialect. More specifically, he says: "The attempt of some to find the Albanian literary standard in the dialect of Elbasan 
has finished without any useful results because in this dialect there was not any value literature" (Ismajli, 2005, p. 90).

Section ended without any decision regarding the dialect basis of the national literary language, while the state executive bodies did not stopped imposing Tosk as the sole basis of the national literary language in public uses.

During the discussions held at this session it was somewhat about the literary variety of the dialect of Elbasan and it is not occasional but it is based on the historical data. In fact, if we look at the history of the standard Albanian language, we notice that the literary Elbasan dialect, in certain historical moments, enjoyed the status of being a common variant of the Albanian language. The first institution in which this decision was made was the Congress of Elbasan (1909) in which, in paragraph 11 it was stated: "The Congress advises all writers to use in their writings the dialect of Elbasan, because it is the language understood in all parts of Albania".

Further, it proceeded with the Literary Commision of Shkodra (1916), in which was unanimously approved the thesis of Gurakuqi for the selection of the Elbasan dialect as a writing language, "The dialect of Elbasan, in the perspective of its forms as well as its syntax, is a bridge between the Tosk and Gheg, it should be chosen as a writing language with those orthographic rules which we consider to be right and reasonable. By making this decision, the Literary Commission must always keep account of the task to make the necessary research, in order to find the medium, which could approach the dialectic changes of both dialects " (Çeliku, 2009, p. 125).

The government Decision of 1923 gives back to the literary Elbasan dialect the status of an official language, reflected in the official Newspaper entitled "On the official dialect", where it was written: "Based on the decision no. 148, 13-I-1923 of the Prime Ministry you are please to authorize all the offices to always use the dialect of Elbasan in their writings and official acts, which as accepted as a common dialect of our country." (14-I-23 n. 763) (Fletorja zyrtare, 1923) Meanwhile, the subsequent history shows us that the spread of the Dialect of Elbasan was prevented by several major factors (Myrta, 2014, p. 69). (In addition to these milestones, there are also early rumors and views by Albanian writers and thinkers regarding the literary Elbasan dialect as a possible common linguistic variant for the Albanians.)

However, beyond the discussions held in two sessions, the facts actually show that Gheg literary began to be removed from the press back in 1954, and in 1946 it was removed from textbooks, while this reality was the result of a series of previously taken initiatives. In 1951, the Ministry of Education decided that in the first grades of primary school was teaching north Tosk. So, practically, in 1952, the literary Tosk, administratively, from above, was made the language of the press, school, radio, and translations, dictionaries, grammar, etc. (Beci, 1992, p. 53).

The 1952 scientific session was an attempt to put a "scientific stamp" to a phenomenon that had already been administratively resolved at its best literary Tosk. If in 1952 it could not be officially justified this solution, it is explained with the reaction of such popular researchers as A.Xhuvani, E.Çabej etc. Among others, in 1952, they claimed that the writers could still write in their dialect. They saw no disaster in the fact that "Albanians did not write all their own language in the same form, but with two different dialectal forms".

During this period, Sterjo Spase in his speech, "Our school and the national written language" kept this attitude: In the school year 1945-1946 the Ministry of Education had made a first change in the language of textbooks, readings of the 4 th and $5^{\text {th }}$ class, which before were compiled in the Elbasan dialect, were made in both dialects. Thus, the linguistic anarchy grew even more, according to him. Meanwhile, the use of Tosk in propaganda and the press grew and strengthened, and "the Ministry of Education decided that the 1951-1952 school year for all schools of the Republic all the primary school readings were to be developed taking into account the dialect that was everywhere affirmed as a national written language, thus the Tosk dialect. For the 1952-1953 school years in this linguistic variant were designed grammar, part of Phonetics and morphology for the elementary school. Even the textbooks of different subjects were written based on this dialect. "Spase argued why it was necessary for schools to use a single variant of the literary language based on Tosk: because the children out of the school, in print, radio, conferences etc. encountered only the literary language based on this dialect.

As can be noted, given the held attitudes, especially in the two sections of the 1952, we can say that, during this phase of the development of our standard Albanian language, still it could not be decided on an final model on which would rely the common language for all Albanians. However, if we refer to the attitudes held, it appears that not only there were no possibilities of a return of the thesis on the Elbasan dialect, but further there were reinforced the attitudes on the literary Tosk. If we go further in of the development of a standard performance of Albanian, will note that this position will be further strengthened, to finalize at the Spelling Congress in 1972, where it was decided that the Tosk literary linguistic variant would constitute the basis on which the Albanian standard would rely.

\section{Conclusions}

Although the efforts to create a standard variant of Albanian had started a long time ago, the period after the Second 
World War liberation, found Albanian still incomplete. However, by this period the literature of Elbasan dialect was powerful, which it did not last very long, because in 1945 they took decisions about removing Gheg dialect from the press and from the schools language.

Meanwhile, the most important events of this period associated directly to the creation of standard Albanian, were 2 sections in 1952. Their primary purposes were the discussions about the dialect base of standard Albanian where the main discussion was about the fact which of the dialects Gheg or Tosk would serve better. In both of sections discussions the main theme was about the same - discussions and many important scholars like: D. Shuteriqi, A. Xhuvani, S. Malesova, M. Reso, I. Ajeti, N. Resulli etc. After the discussions in both of sections they observed a desire about the creation in the base of Tosk dialectal literature. Discussions like this of course were based in facts and justifications about Tosk dialect.

Among the reasons mentioned during the discussions of the main thesis, it is worth mentioning those related to the fact that south literature was richer, more widespread and most of the ideologues of this period were from the south of the country, even and Socialist Party of Albania used Tosk dialect.

Despite these developments, we can say that during this period, although there were taken very important steps towards finalizing the process of creating standard Albanian version, we still cannot talk about the presence of such an option about Albanian.

\section{References}

Beci, Bahri, "Problems of formation of standard literary Albanian", Scientific conference "Literary national language and Albanians nowdays", Tiranë, 20-21 November 1992.

Çeliku, Mehmet, "Monastery Congress after 100 years in standard Albanian issues, Tiranë, 2009, Official Journal, Tiranë, 1923.

Gjinari, Jorgji;\& Shkurtaj Gjovalin, "Dialects" Tiranë, 2000.

Ismajli, Rexhep, "Standard languages and identities story.Tiranë, 2005.

Myrta, Manola, "On the traits of literary elbasanisht", desertation theme, Tiranë 2014, p. 82. "Albanian Literary committee in Shkodër, Shkodër, 1997.

Shkam i Letanit, "The sun", article from "Elbasani", Elbasan, 1909. http://www.balkanweb.com/kultur\%C3\%AB/2691/shkurtaj-To reedit the improved spelling rules 128852.html 